\title{
The Use of Simulated Body Fluid (SBF) for Assessing Materials Bioactivity in the Context of Tissue Engineering: Review and Challenges
}

\author{
Francesco Baino ${ }^{1, *(1)}$ and Seiji Yamaguchi ${ }^{2}$ \\ 1 Institute of Materials Physics and Engineering, Department of Applied Science and Technology, \\ Politecnico di Torino, Corso Duca degli Abruzzi 24, 10129 Torino, Italy \\ 2 Department of Biomedical Sciences, College of Life and Health Sciences, Chubu University, \\ Aichi 487-8501, Japan; sy-esi@is.c.chubu.ac.jp \\ * Correspondence: francesco.baino@polito.it; Tel.: +39-011-090-4668
}

Received: 25 September 2020; Accepted: 26 October 2020; Published: 29 October 2020

\begin{abstract}
Some special implantable materials are defined as "bioactive" if they can bond to living bone, forming a tight and chemically-stable interface. This property, which is inherent to some glass compositions, or can be induced by applying appropriate surface treatments on otherwise bio-inert metals, can be evaluated in vitro by immersion studies in simulated body fluid (SBF), mimicking the composition of human plasma. As a result, apatite coating may form on the material surface, and the presence of this bone-like "biomimetic skin" is considered predictive of bone-bonding ability in vivo. This review article summarizes the story and evolution of in vitro bioactivity testing methods using SBF, highlighting the influence of testing parameters (e.g., formulation and circulation of the solution) and material-related parameters (e.g., composition, geometry, texture). Suggestions for future methodological refinements are also provided at the end of the paper.
\end{abstract}

Keywords: bioactivity; simulated body fluid (SBF); biomaterials; apatite; bioactive glass; titanium; tissue engineering

\section{The Story of Simulated Body Fluid (SBF) Development}

The assessment of bioreactivity, including bone bonding of implant materials, has been generally performed by an in vivo animal test, which was possibly started by Levert in 1829 [1], who studied gold, silver, lead, and platinum specimens in dogs. Although various types of artificial materials, such as steel, $\mathrm{Co}-\mathrm{Cr}$ alloy, alumina, and titanium, have been implanted into bone defects, they were isolated from surrounding bone tissue due to fibrous connective tissue at the interface between the bone and implant. This was a normal protective reaction of the living body against foreign materials.

The first man-made material that bonded to bone without any fibrous tissue was the $\mathrm{Na}_{2} \mathrm{O}-\mathrm{CaO}-\mathrm{SiO}_{2}-\mathrm{P}_{2} \mathrm{O}_{5}$ glass reported by Hench and his colleagues in 1972 [2]. This discovery stimulated many researchers to develop various kinds of "bioactive materials", such as sintered hydroxyapatite, $\beta$-tricalcium phosphate, Ceravital-type glass-ceramic containing apatite, and glass-ceramic $\mathrm{A}-\mathrm{W}$ containing apatite and wollastonite, all of which directly bond to living bone [3]. Although these ceramic materials were successfully used as artificial middle ear small bones (ossicles), periodontal fillers, bone substitutes, iliac crest repair, and even in artificial vertebrae, their mechanical strength and fracture toughness were insufficient to use under load-bearing conditions, such as occurring in the femoral bone. It was, thus, greatly desired to confer bone-bonding capability on metals that are durable under load-bearing conditions. However, there was no clear indication of how to develop such materials. 
When the various interfaces between bone and the bioactive materials were investigated, apatite layers were always found [4-6]. Based on these results, Kokubo and his colleagues speculated that materials forming an apatite layer on their surfaces are able, in principle, to bond to bone. They also speculated that this apatite formation is reproducible in vitro, and invented an acellular simulated body fluid (SBF) in which the ion concentrations and $\mathrm{pH}$ were nearly equal to these factors in human blood plasma in 1991 [7]. They found that the in vivo apatite formation of glass-ceramic A-W, Bioglass ${ }^{\circledR}$, glass-ceramic Ceravital ${ }^{\circledR}$, and sintered hydroxyapatite were successfully reproduced in vitro when these materials were simply soaked in SBF at $36.5^{\circ} \mathrm{C}$. They proposed that the bone-bonding capability of a given material could be evaluated by examining the apatite-forming capability on its surface in SBF.

The invention of SBF accelerated the development of bioactive materials since it catalyzed systematic study of apatite formation in various types of materials of various composition. Otsuki et al. investigated $\mathrm{CaO}-\mathrm{SiO}_{2}-\mathrm{P}_{2} \mathrm{O}_{5}$ system glasses and reported in 1992 that $\mathrm{CaO}-\mathrm{SiO}_{2}$ glass of a certain composition is able to form apatite in SBF [8]. Li et al. reported that $\mathrm{SiO}_{2}$ gel prepared by a sol-gel method formed apatite, also, in 1992 [9]. These results indicate that both $\mathrm{CaO}$ and $\mathrm{P}_{2} \mathrm{O}_{5}$, which are bone components, are not essential for apatite formation. Later, in the period 1994-2001, metallic oxide gels of $\mathrm{TiO}_{2}, \mathrm{ZrO}_{2}, \mathrm{Nb}_{2} \mathrm{O}_{5}$, and $\mathrm{Ta}_{2} \mathrm{O}_{5}$ were also found to form apatite in SBF [10-13]. These results indicated that certain kinds of hydroxyl groups, such as $\mathrm{Si}-\mathrm{OH}, \mathrm{Ti}-\mathrm{OH}, \mathrm{Zr}-\mathrm{OH}, \mathrm{Nb}-\mathrm{OH}$, and Ta-OH, are effective for inducing apatite formation in the body environment. This provided an indication of the general means of how to confer bone-bonding capacity on metals.

In 1996, Kim et al. reported that titanium and its alloys formed apatite on their surfaces in SBF when they had been simply immersed in $5 \mathrm{~mol} / \mathrm{L} \mathrm{NaOH}$ solution and subsequently subjected to a heat treatment at $600{ }^{\circ} \mathrm{C}$, as shown in Figure 1 [14,15]. This apatite formation was attributed to a sodium titanate layer with abundant $\mathrm{Ti}-\mathrm{OH}$ groups that formed on the metals. An in vivo animal test performed by Yan et al. showed that the $\mathrm{NaOH}$-heat-treated titanium tightly bonded to bone via the apatite layer that had formed on the treated metal surface in the living body [16]. The $\mathrm{NaOH}$ and heat treatment was then applied to a porous Ti metal layer on the surface of an acetabular shell and femoral stem of a total artificial hip joint made of Ti-6Al-2Nb-Ta alloy, and this device has been in clinical use since 2007 [17]. A similar treatment was also applied to a spinal fusion device that has been in clinical use, without the need of any autograft, since 2018. This is in contrast with conventional Ti spinal fusion devices that require an autograft for fixation, since they cannot bond to living bone.

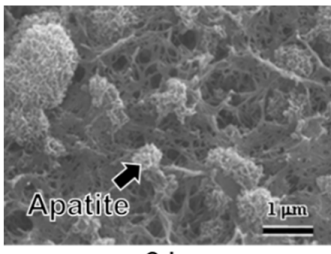

$6 \mathrm{hr}$

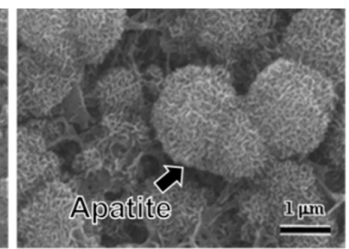

$12 \mathrm{hr}$

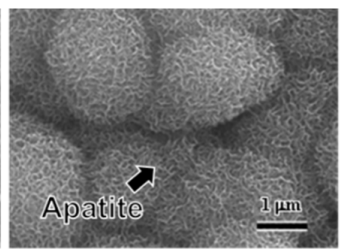

$24 \mathrm{hr}$

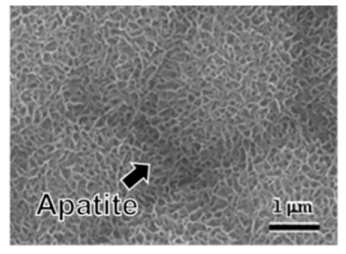

$72 \mathrm{hr}$

Figure 1. Apatite formation and growth on the surface of Ti subjected to $\mathrm{NaOH}$ and heat treatment by soaking in in simulated body fluid (SBF) (reproduced from [15]). The needle-like shape of bone-like apatite nanocrystals can be appreciated.

The SBF method, as the in vitro indicator of the bone-bonding capability of materials, came to be widely accepted by material scientists immediately after its invention. Since the original form of SBF lacked the $\mathrm{SO}_{4}{ }^{2+}$ ions that are present in human blood plasma, this was corrected in 1991 . The corrected SBF is still richer in $\mathrm{Cl}^{-}$ions and poorer in $\mathrm{HCO}^{3-}$ ions than human blood plasma. Thus, detailed studies to correct this difference were performed in 2003 and 2004 [18-20]. After careful assessment of its stability and the reproducibility of the apatite formation on synthetic materials, the corrected SBF with a refined recipe that allowed for easy preparation was proposed to the Technical Committee ISO/TC150 of the International Organization for Standardization (ISO). In 2007, the SBF was registered 
as ISO 23317, which is the standard solution for the in vitro evaluation of the apatite-forming ability of implant materials [21].

In 2006, Kokubo et al. summarized the correlation of in vivo bone bonding and in vitro apatite formation on various kinds of materials [22]. They described the quantitative correlation of apatite formation in SBF with in vivo bone bioactivity. On the other hand, they noted that there are a few exceptional cases in which this criterion is not valid, e.g., if the materials are highly resorbable or cytotoxic. $\beta$-tricalcium phosphate and natural calcite bond to living bone without forming an apatite layer on their surfaces. In contrast, natural abalone shell has apatite form on its surface in SBF, but does not bond to living bone.

Some concerns on the validity of SBF were proposed by Bohner et al. and Pan et al. in 2009 and 2010 [23,24]. Bohner et al. pointed out "(i) the absence of proteins, whereas they are known to play an essential role in controlling apatite nucleation (nucleation inhibitors); (ii) the addition of tris(hydroxymethyl)aminomethane (Tris) to buffer SBF solutions; and (iii) the absence of any control for the carbonate content of the SBF solutions, although carbonates act as pH buffer in serum." Pan et al. pointed out "bioactivity cannot be predicted from observed apatite forming ability simply on immersion in a so-called simulated body fluid" and suggested that the development of osteoconductive surfaces "can only be done through testing in vivo or, using osteoblasts under realistic conditions, in vitro". Despite the limitations of SBF and these concerns, however, SBF has remained a powerful tool for predicting in vivo bone bonding ability. In 2014, Zadpoor reviewed 33 published studies available in the literature at the time, in all of which both the in vitro apatite forming ability and in vivo performance of two or more biomaterials were compared [25]. He concluded that in the clear majority of the studies (25/33 cases), the SBF immersion test proved successful in predicting the relative in vivo bioactivity of the materials. However, he suggested that "the details of the test protocols and the mechanisms of bioactivity of tested biomaterials should be carefully considered in the design of SBF immersion tests and in interpretation of their results".

\section{The Role of SBF Composition}

As summarized By Nommeots-Nomm et al. [26] in a valuable review paper, a number of solutions have been proposed and used over the past 30 years to test the apatite-forming ability of biomaterials, including SBF, Tris buffer solution, dilute phosphate solutions and various cell culture medium formulations. Since 2007 , the standard solution that is internationally adopted for in vitro bioactivity testing is the SBF formulation included in ISO 23317.

Perhaps the most common and oldest concern about the validity of this acellular solution is that SBF only reproduces the composition of the inorganic part of human plasma but does not contain any relevant bio-organic compounds, such as proteins, which are instead present in real biological fluids. This aspect was thought to be responsible for the differences found between biological apatite in natural calcified tissues and bone-like apatite layer formed on the surface of biomaterials upon soaking in SBF.

A series of studies published in 2003-2007 focused on this issue and investigated the influence of glucose [27], bovine serum albumin (BSA) [28], and cow's milk [29] on the precipitation of a bone-like apatite layer from SBF. A similar behavior of BSA- and milk-containing SBF in terms of apatite formation rate was noted, but the studies were then discontinued by that group of researchers. Perhaps this was due to the problems of storage and preservation of the protein-modified solutions: if acellular SBF can be safely stored in a refrigerator at $5-10{ }^{\circ} \mathrm{C}$ for 1 month, preservation of BSA- or mill-containing SBF is obviously more difficult and shorter. Furthermore, sterile conditions are needed for both storage and testing. More recently, Magyari et al. [30] reported that the growth of an apatite-like layer on sol-gel bioactive glasses was lower if BSA-containing SBF was used compared to conventional SBF because calcium bonded to albumin. The inhibitory effect of BSA on hydroxyapatite during immersion in SBF was also observed by Zhao et al. [31]. 
Using cell culture media, such as Dulbecco's modified Eagle medium (DMEM), has also been proposed as an alternative to SBF in order to better mimic "biological" conditions during in vitro bioactivity tests. Rohanova et al. [32], however, demonstrated that DMEM is unsuitable for such tests as it promotes the precipitation of calcium carbonate $\left(\mathrm{CaCO}_{3}\right)$ but does not allow apatite formation; actually, this is not surprising as DMEM contains a high concentration of $\mathrm{HCO}^{3-}$ ions (ten times higher compared to SBF), which favors the precipitation of $\mathrm{CaCO}_{3}$ on the surface of bioactive glasses that release high amounts of $\mathrm{Ca}^{2+}$ ions during the test [33]. Furthermore, the use of DMEM requires the additional need to maintain sterile conditions during the bioactivity test.

Formation of calcium carbonate instead of or concurrently with apatite has also been observed to occur on the surface of bioactive glasses when "old" SBF formulations are used [18,19]. Thus, false negative results (i.e., a material may be incorrectly considered non-bioactive) could be due to following non-standard experimental procedures. Some papers in the literature-few, luckily-still suffer from such a mistake, as discussed in a recent review paper [34]; on the contrary, using the standard SBF formulation is key to obtain reliable results that can be robustly compared with those reported in similar experiments by different research teams.

\section{The Role of Materials Chemistry}

The chemical nature of the biomaterial considered indeed plays a key role on its bioactive properties; therefore, its apatite-forming ability upon immersion in SBF is strongly influenced accordingly. Unless properly treated, metallic materials are typically unable to induce the formation of apatite deposits on their surface in vitro; this topic will be specifically discussed in Section 5. On the contrary, some special glass formulations exhibit inherent bioactive properties. Hench [35] first proposed a five-stage process, conceptually similar to the mechanism of soda-lime glass corrosion, to explain the nucleation, growth and crystallization of bone-like apatite phases on the surface of silicate glasses upon immersion in aqueous solution:

(1) Glass-fluid ion exchange, involving the exchange of monovalent $\left(\mathrm{Na}^{+}\right)$and bivalent cations $\left(\mathrm{Ca}^{2+}\right)$ from the glass with protons $\left(\mathrm{H}^{+}\right)$from the solution. This will lead to the formation of $\mathrm{Si}-\mathrm{OH}$ (silanol bonds) on the glass surface;

(2) Rising of $\mathrm{pH}$ towards alkalinity, attack of Si-O-Si bonds by hydroxyl ions and formation of soluble silica $\mathrm{Si}(\mathrm{OH})_{4}$;

(3) Condensation and polymerization of silanol groups, with formation of a silica-rich amorphous layer (silica gel). The gel can absorb ions from the solution and, thus, be a "reactor" for apatite formation;

(4) Diffusion of calcium $\left(\mathrm{Ca}^{2+}\right)$ and phosphate $\left(\mathrm{PO}_{4}{ }^{3-}\right)$ ions through the silica gel and from the solution, leading to the formation of an amorphous calcium-phosphate film on the top of the silica gel;

(5) Crystallization of the calcium-phosphate layer and formation of hydroxyapatite, which is morphologically and crystallographically similar to bone bio-apatites.

Although the glass dissolution and apatite formation can last for a quite long period of time, the nucleation of the first crystals of hydroxyapatite is relatively fast and strongly depends on the molar percentage of $\mathrm{SiO}_{2}$ in the glass composition [36]. If the amount of $\mathrm{SiO}_{2}$ is below $53 \mathrm{~mol} . \%$ in melt-derived glasses, hydroxyapatite crystallizes in less than $2 \mathrm{~h}$ and the glass can then chemically bond to living bone via this biomimetic interface; these glasses can also bond to soft collagenous tissues [37] (Figure 2). If the amount of $\mathrm{SiO}_{2}$ is increased up to $58 \mathrm{~mol} \%$, the hydroxyapatite crystallization is slower and may take two days before happening. If the amount of $\mathrm{SiO}_{2}$ is higher than $60 \mathrm{~mol} . \%$, there was no evidence of hydroxyapatite crystallization after 1 month of immersion in SBF, although the formation of an amorphous calcium-phosphate layer was observed [36]. 


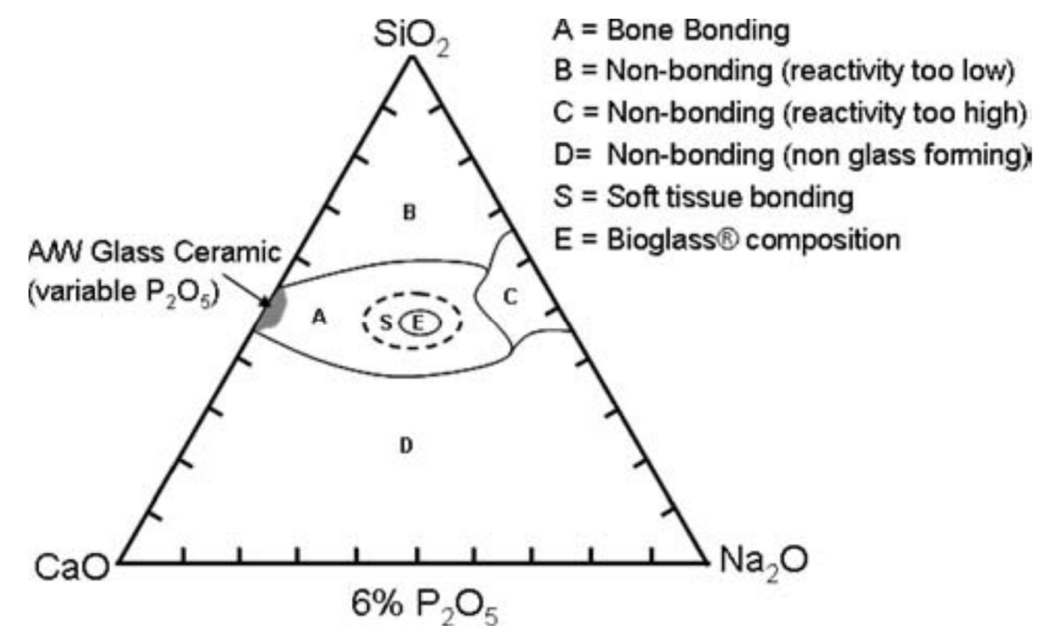

Figure 2. Compositional diagram used to design silicate bioactive glasses. Reproduced from [37] Hench, L.L. The story of bioglass. J. Mater. Sci. Mater. Med. 2006, 17, 967-978. Copyright 2006 Springer Nature.

The ability to react and dissolve within SBF (or equivalent solutions) and induce apatite formation on the surface is strongly related to the glass network connectivity. The network of silicate glasses is formed by silica tetrahedra that are bonded together via $\mathrm{Si}-\mathrm{O}-\mathrm{Si}$ bonds [38]. Network modifiers such as $\mathrm{Na}_{2} \mathrm{O}, \mathrm{CaO}, \mathrm{MgO}$, or $\mathrm{K}_{2} \mathrm{O}$ locally disrupt the glass network by breaking the $\mathrm{Si}-\mathrm{O}-\mathrm{Si}$ bonds and forming non-bridging oxygen [39]. In terms of glass dissolution kinetics, the less connected the glass network, the faster the glass dissolution [40]. This is the reason why melt-derived glasses with high silica content (above 60 mol.\% [36]) are non-bioactive. The number of bridging oxygens of a silica tetrahedron can be expressed using the notation $\mathrm{Q}^{\mathrm{n}}$, where $\mathrm{n}$ is the number of bridging oxygens and may range from 0 to 4. It was reported that the network of $45 \mathrm{~S} 5$ glass $\left(45 \mathrm{SiO}_{2}-24.5 \mathrm{CaO}-24.5 \mathrm{Na}_{2} \mathrm{O}-6 \mathrm{P}_{2} \mathrm{O}_{5}\right.$ wt. $\left.\%\right)$, which is highly bioactive, is mainly composed of chains and rings of $\mathrm{Q}^{2}$ (almost $70 \%$ of tetrahedra have just two bridging bonds), while the remaining part is $\mathrm{Q}^{3}$ [41]. Starting from the glass composition, one can predict the network connectivity (i.e., the average number of bridging oxygens per each atom of $\mathrm{Si}$ ), $\mathrm{N}_{\mathrm{c}}$, as:

$$
\mathrm{N}_{\mathrm{c}}=\frac{4\left[\mathrm{SiO}_{2}\right]-2\left[\mathrm{M}_{2}^{\mathrm{I}} \mathrm{O}+\mathrm{M}^{\mathrm{II}} \mathrm{O}\right]+6\left[\mathrm{P}_{2} \mathrm{O}_{5}\right]}{\left[\mathrm{SiO}_{2}\right]}
$$

where $\mathrm{M}_{2}^{\mathrm{I}} \mathrm{O}$ and $\mathrm{M}^{\mathrm{II}} \mathrm{O}$ are the mono- and divalent modifier oxides, respectively, that are present in the glass. Hence, the bioactivity of the material can be estimated knowing that, in order to be bioactive, a glass should exhibit a value of $\mathrm{N}_{\mathrm{c}}$ in the range of 1.8 to 2.6 [41].

Although the multistep bioactivity mechanism described by Hench was initially developed for melt-derived 45S5 glass, it can be extended to most of bioactive silicate glasses produced either by melting or sol-gel process [42]. Some types of glass-ceramics (e.g., apatite-wollastonite (A-W)) were also reported to exhibit a similar behavior, forming a surface apatite layer in SBF albeit the silica gel layer was not detected [43]. It was also noted that the presence of crystalline phases can delay the formation of a surface apatite layer, but does not totally suppress the bioactivity in vitro even if crystallinity reaches $100 \%$ [44].

Borate-based glasses are more reactive than silicate systems in contact with aqueous media, such as $\mathrm{SBF}$, and convert faster to hydroxyapatite than traditional bioactive glasses based on $\mathrm{SiO}_{2}$ as a network former. In principle, the bioactivity mechanism of borate glasses is similar to that of silicate glasses, but involves the formation of a borate-rich gel layer instead of silica gel. Fast dissolution is thought to be related to the structural changes in the glass network with increasing $\mathrm{B}_{2} \mathrm{O}_{3}$ content, since $\left[\mathrm{BO}_{3}\right]$ trihedra cannot fully form a three-dimensional network compared to silica. Therefore, the dissolution-precipitation reactions occur continuously until the borate glass is fully converted to hydroxyapatite [45]. 
Phosphate-based glasses exhibit a typical tendency to quickly dissolve in aqueous solutions [46], which often precludes the formation of a stable surface apatite layer unless the glass composition is carefully designed to slow down the glass dissolution kinetics [47]. By adding modifiers (e.g., $\mathrm{TiO}_{2}, \mathrm{CuO}$, or $\mathrm{Fe}_{2} \mathrm{O}_{3}$ ), the dissolution rate of phosphate systems can be varied from a few hours to months [48]. The low stability of such glasses is due to the asymmetry of $\left[\mathrm{PO}_{4}\right]$ tetrahedra and the easy tendency to hydration of $\mathrm{P}-\mathrm{O}-\mathrm{P}$ bond [46].

Dissolution tests using phosphate dilute solutions or the Tris buffer solution are often performed as an alternative to immersion studies in SBF for borate- and phosphate-based glasses.

\section{The Role of Materials Geometry and Texture}

The "geometrical" characteristics of samples can play a significant role on apatite formation in $\mathrm{SBF}$, especially if the considered materials are inherently surface-reactive, such as bioactive glasses. In general, it is well known that the higher the specific surface area, the faster the ion-exchange mechanisms behind bioactive glass reactivity [49].

There is convincing evidence demonstrating that texture plays a predominant role over glass compositions as regards bioactive properties. It was found that, in non-porous melt-derived glasses, the content of $\mathrm{SiO}_{2}$ should be less than $60 \mathrm{~mol}$.\% to allow apatite formation on the surface in vitro and bonding to bone in vivo [50]; however, apatite can still form on the surface of SBF-treated glasses containing up to $90 \mathrm{~mol} \%$ of $\mathrm{SiO}_{2}$ if the material is obtained via sol-gel process due to inherent nanoporosity and high specific surface area available for glass-fluid interfacial reactions (above $10 \mathrm{~m}^{2} / \mathrm{g}$ vs. $0.10-0.30 \mathrm{~m}^{2} / \mathrm{g}$ for melt-derived products) [51]. This effect is further emphasized when a structure-directing agent is incorporated in the sol-gel process as a template for the development of an ordered mesoporous structure (specific surface area of the final calcined material above $100 \mathrm{~m}^{2} / \mathrm{g}$ ) [52]. For example, hydroxyapatite crystals could form on mesoporous glass membranes with $80 \mathrm{SiO}_{2}-15 \mathrm{CaO}-5 \mathrm{P}_{2} \mathrm{O}_{5}$ (mol.\%) composition upon soaking in SBF for just $8 \mathrm{~h}$, while the corresponding melt-derived material would be invariably considered an almost bio-inert material [53]. Even pure mesoporous silica (MCM-41 and SBA-15) was shown as able to form a surface apatite layer upon immersion in SBF due to its exceptional textural properties $[54,55]$, but this process still requires too long a time to figure out a reliable bone-bonding application.

Sol-gel silicate glass-ceramics were also reported to exhibit good apatite-forming capability in SBF after $48 \mathrm{~h}$ regardless of the presence of crystalline phases [56], which instead often lead to a dramatic decrease of bioactivity in melt-derived materials [44].

In general, the extent of surface area, associated to both pore walls and outer surface, plays a pivotal role in bioactivity assessment. Sepulveda et al. [57] investigated the dissolution kinetics of melt-derived $45 \mathrm{~S} 5$ glass powders having three dimensional ranges, i.e., fine (5-20 $\mu \mathrm{m})$, medium (9-300 $\mu \mathrm{m})$, and coarse $(90-710 \mu \mathrm{m})$ sizes, during immersion in SBF. Overall, the dissolution results were directly correlated with the glass particle size in spite of an overlap of the size ranges, with the highest dissolution occurring for the smallest particles $(5-20 \mu \mathrm{m})$. Accordingly, the $\mathrm{pH}$ increment towards alkalinity and apatite formation rate were faster as the particle size decreased; this trend (i.e., the finer the size, the higher the area, the higher the reactivity) was consistent with calcium dissolution and reduction in phosphorous concentration in the solution (phosphate "sequestration"), which is a proof of the apatite formation on the material surface.

Similar conclusions were reported in another study, [58], comparing the bioactive behavior of 45S5 glass in two well-distinct particle size ranges, i.e., $45-90 \mu \mathrm{m}$ and $90-710 \mu \mathrm{m}$. Dissolution experiments were carried out in SBF at a fixed mass-to-volume ratio of $1.5 \mathrm{mg} / \mathrm{mL}$. While the ion release tests shown in this publication did not reveal any significant difference between the ion concentration of the two samples, FTIR and XRD results suggested that apatite formed faster on the glass with a smaller size, with typical phosphate bands at 560 and $600 \mathrm{~cm}^{-1}$ being more pronounced after 1-day immersion, compared to coarse glass. The faster apatite-forming rate was associated with the higher specific 
surface area of fine glass particles, allowing faster ion exchange, and reaching supersaturation of the solution faster than large glass particles.

The same research group also elucidated how much the geometry of samples can affect the test execution and play a role from a methodological viewpoint [58]. They compared the method described in ISO 23317, which uses a fixed sample surface area-to-solution volume ratio, with another method, developed by the Technical Committee 4 (TC04) of the International Commission on Glass (ICG), which uses a fixed mass-to-volume ratio. Using the ISO method obviously led to different mass-to-volume ratios for different samples, depending on the glass particle size and surface area; however, if compositions with ultra-high surface area are used (above $100 \mathrm{~m}^{2} / \mathrm{g}$ like in sol-gel and mesoporous glasses [59]), this approach prescribes using a so low mass of glass that the experiments cannot be performed [58]. It is worth noting that the ISO standard was initially developed for solid samples with well-defined external geometry and shape (small tiles or cylinders), and Kokubo and Takadama [22], whose work was the basis of this standard, also recommended to further increase the volume of SBF for porous samples having an "effective" surface area (due to pore walls) higher than the outer one-but they did not quantify the extent of such an increment. Furthermore, the low mass-to-volume ratio deriving from the ISO method in case of powders or scaffolds could significantly delay the formation of apatite on the surface of samples. In order to overcome all these imitations, Macon et al. [58] recommended the use of a fixed mass-to-volume ratio of $1.5 \mathrm{mg} / \mathrm{mL}$ when bioactive glasses are tested in SBF in the form of powders or granules.

These methodological aspects are crucial to avoid another problem that has been sometimes observed during immersion studies of bioactive glasses in SBF, i.e., the precipitation of $\mathrm{CaCO}_{3}$ instead of or concurrently with apatite on the surface of samples. This typically occurs if a too small volume of solution, or, in other words, a too high solid-to-liquid ratio, is used. As a result, the high concentration of $\mathrm{Ca}^{2+}$ ions in SBF may lead to $\mathrm{CaCO}_{3}$ precipitation [34]. From another perspective, it is apparent that the formation of $\mathrm{CaCO}_{3}$ is favored when glass particles with ultra-high surface area are tested if the volume of SBF is not properly selected. This means that the mass-to-volume ratio of $1.5 \mathrm{mg} / \mathrm{mL}$ suggested by Macon et al. [58] may still be too high to reveal the bioactive properties of ultra-porous or ultrafine materials, leading to an underestimation of the bioactivity or even false negative results due to $\mathrm{CaCO}_{3}$ precipitation. Early evidence of this problem was reported by Macon et al. [58] and Maclovic et al. [60], who observed the formation of $\mathrm{CaCO}_{3}$ on the surface of mesoporous and $45 \mathrm{~S} 5$ nano-sized glass particles, respectively, after 1 day in SBF (Figure 3). Thus, a future optimization of experimental protocols for bioactivity assessment of highly-porous bioactive glasses should take into account this issue, rethinking the "optimal" volume of SBF to use with mesoporous and ultrafine glass micro-/nano-particles and probably shifting the mass-to-volume ratio below $1.5 \mathrm{mg} / \mathrm{mL}$.
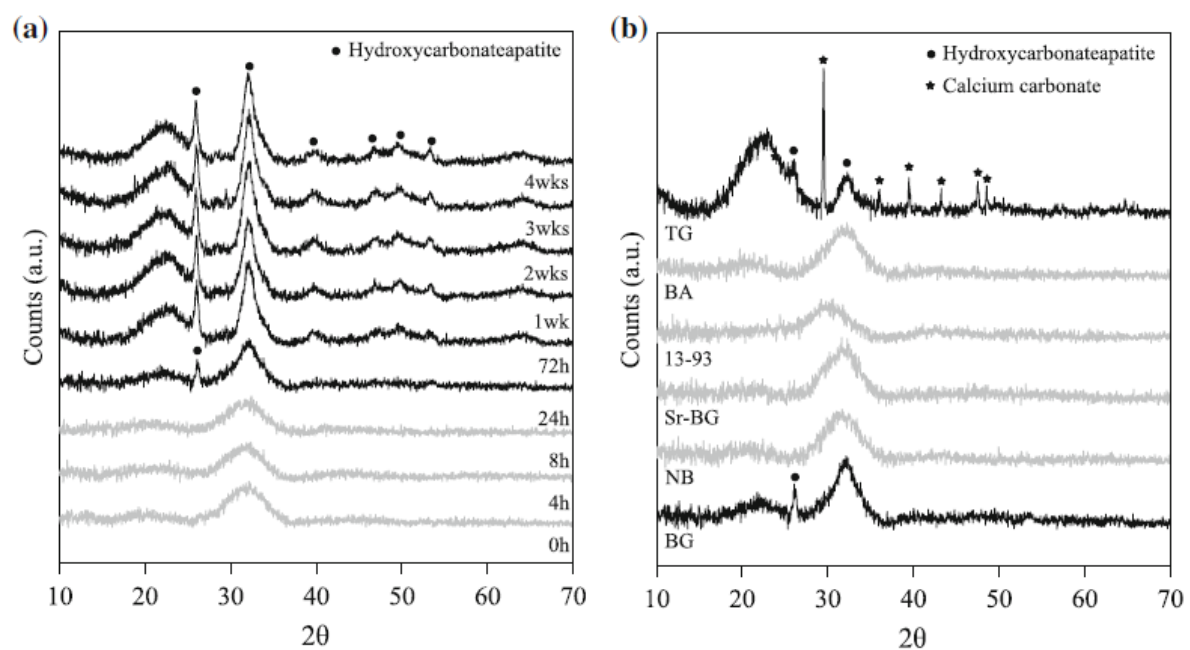

Figure 3. XRD spectra of (a) $45 \mathrm{~S} 5$ glass particles (size 45-90 $\mu \mathrm{m}$ ) after 0 to 4 weeks of immersion in SBF and (b) different silicate glass compositions after $24 \mathrm{~h}$ immersion in SBF. 
All of the glasses were produced by melting, except for the glass TG, which was obtained by sol-gel process. Reproduced from [58] Macon, A.L.B.; Kim, T.B.; Valliant, E.M.; Goetschius, K.; Brow, R.K.; Day, D.E., et al. A unified in vitro evaluation for apatite-forming ability of bioactive glasses and their variants. J. Mater. Sci. Mater. Med. 2015, 26, 115. Copyright 2015 Springer Nature.

Furthermore, oxide substitutions in the glass composition may also carry the need for adjusting the mass-to-volume ratio used during immersion studies. When replacing an element with another of lower (e.g., Na with Li) [61] or higher atomic weight (e.g., Ca with Sr) [62] on a molar base, the molar weight of the glass changes. If a constant mass of glass is used for the experiments, the molar amount changes with composition, which has been shown to affect ion release during immersion studies [61].

The osseointegration of metallic implants also greatly depends upon the material structure and texture. Among the various parameters, surface roughness has received a great deal of attention in efforts to improve the bone-implant contact [63,64], and various techniques for turning, smoothing, blasting, and chemical etching, as well as electrochemical and deposition methods, have been developed to control the surface roughness of implants [65-67]. A highly roughened surface $(\operatorname{Ra}>5 \mu \mathrm{m})$ is produced by plasma spraying and grid-blasting, while a moderately roughened surface $(\operatorname{Ra}=1-5 \mu \mathrm{m})$ is produced by acid etching and anodization. A smooth surface $(\mathrm{Ra}<1 \mu \mathrm{m})$ is obtained by a smoothing process performed by means of grit-paper [68].

Since the processing often alters not only the surface roughness, but also chemical factors, such as wettability and the surface charge caused by the residue of solid/solution and surface oxidation, a systematic study is needed to investigate the effect of roughness exclusively. Hacking et al. [69] compared bone apposition on four kinds of titanium that were polished, grit-blasted, plasma-sprayed with hydroxyapatite, or plasma-sprayed with hydroxyapatite, and masked with a very thin layer of titanium by means of physical vapor deposition (titanium mask). The titanium mask isolated the chemistry of the underlying hydroxyapatite layer without functionally changing its surface topography or morphologic features. When these were implanted into the femurs of dogs, the bone apposition was only $2.8 \%$ on as-polished Ti with an average roughness ( $\mathrm{Ra}$ ) of $0.09 \mu \mathrm{m}$, while it increased to $23 \%$ on grid-blasted $\mathrm{Ti}$ with an $\mathrm{Ra}$ of $3.64 \mu \mathrm{m}$. This was further increased to $73.6 \%$ on $\mathrm{Ti}$ with plasma-sprayed hydroxyapatite having an Ra of $5.58 \mu \mathrm{m}$. The bone apposition became 59.1\% when the plasma-sprayed hydroxyapatite was masked with a thin Ti layer with an unchanged Ra. The enhanced osseointegration was understood to have occurred as a result of increased cell activity and mineralization capacity. The effect of the roughness on cell activity has been well summarized by many researchers elsewhere $[63,64]$, and, therefore, this section focuses on the effect of the roughness on mineralization capacity, that is, the apatite formation on the materials that takes place in SBF.

$\mathrm{SBF}$, as well as human blood plasma, is a solution supersaturated with apatite [7], and, thus, apatite formation on materials occurs as a result of the heterogeneous nucleation and growth of the apatite nuclei that spontaneously proceeds by taking up calcium and phosphate ions in SBF once the apatite nuclei have formed [7]. It should be noted that homogenous nucleation rarely occurs in SBF, but nevertheless has been reported in several papers [70]. The apatite nucleation that occurs is affected by both chemical factors such as hydroxyl groups, surface energy and surface charge, as well as physical factors, such as roughness. Chen et al. reported increased apatite formation on $\mathrm{Ti}, \mathrm{Zr}$, and $\mathrm{TiZr}$ alloys when the surface roughness of these metals was increased from $\mathrm{Ra}=0.2$ to $0.6 \mu \mathrm{m}$, followed by $\mathrm{NaOH}$-heat treatment [71]. Sugino et al. reported that apatite formation was observed only on the internal surfaces of machined micro-grooves $500 \mu \mathrm{m}$ deep and $500 \mu \mathrm{m}$ wide on a Ti-15Zr-4Nb-Ta alloy subjected to heat treatment at $500{ }^{\circ} \mathrm{C}$ [72].

Since the utility of porous materials was discovered in the 1970s, numerous investigations on bone ingrowth into porous ceramics [73], polymers [74], and metals [75] have been performed. Among them, porous metals have been a particular focus due to their superior fracture and fatigue resistance properties that are required for load-bearing applications. The moderate porous structure obtained by sintering and additive manufacturing enables blood and cells to enter into the porous 
body, which results in bone ingrowth [76]. The bone ingrowth via the wall of a porous material, i.e., osteoconduction, is highly reliant on the pore size. The porous titanium fabricated by additive manufacturing with fully-interconnected pores in the range of 300-1100 $\mu \mathrm{m}$ exhibited a reasonable amount of bone ingrowth despite differences in porosity and the outer [77-80]. A remarkable increase in bone ingrowth was reported by Takemoto et al. in a study in which the porous titanium prepared by the sintering method, having the pore size of $300-500 \mu \mathrm{m}$, was subjected to $\mathrm{NaOH}$, water, and heat treatment [81]. The treated porous body formed apatite throughout the inner pores in SBF and displayed significantly greater bone ingrowth depth and area after 8 weeks of implantation in a rabbit femoral condyle compared with an untreated porous body. They also showed that the treated porous titanium exhibited osteoinduction, that is, ectopic bone formation in muscle, when implanted into the dorsal muscle of a beagle dog [82]. This type of bone-forming porous titanium has been used in spinal fusion devices in Japan 2018. This device can be fixed to the surrounding bone without using any bone graft, which, in contrast, is required in the other devices currently in use.

\section{The Role of Surface Treatments and Modifications in Materials That Are Initially Non-Bioactive}

There has been clinical demand in the orthopedic and dental fields for both biocompatibility and durable mechanical properties under load bearing conditions. The former is related to the surface characteristics of the material, while the latter is related to the bulk characteristic. The role of the surface modifications is to improve the surface characteristics of the materials so as to make them biocompatible with bone. Titanium metal (Ti) and its alloys intrinsically possess high biocompatibility and mechanical strength, and hence have been widely used as orthopedic devices and dental implants. This biocompatibility is attributed to the stable passive oxide layer that is a few nanometers in thickness that naturally forms on Ti substrate in air and even in water. However, this thin oxide layer does not always achieve stable fixation between the implant and bone for a sufficiently long period after implantation. In order to confer stable bone-bonding capability on Ti and its alloys, surface modification techniques related to hydroxyapatite, sand-blasting/acid-etching, anodic oxidation, chemical treatment and so on have been developed based on the strategies that improve the cell response and mineralization, and recently, the inflammatory response [83]. Among them, alkali-heat treatment and its derivative techniques such as calcification by chemical treatment have been developed in SBF, which is the focus of this section.

A study showing apatite formation on titania gel in SBF [9] suggested that even Ti and its alloys formed surface apatite on their surfaces when abundant Ti-OH groups formed on their surfaces. Based on this suggestion, Ti was soaked in a $0.1-10 \mathrm{~mol} / \mathrm{L} \mathrm{NaOH}$ solution at $40-60^{\circ} \mathrm{C}$ for $6-96 \mathrm{~h}[14,84,85]$ As a result, a lath-like layer developed on the metal surface with an increase in the concentration, temperature and soaking period. This layer was composed of nano-scale pillars of sodium hydrogen titanate $\left(\mathrm{Na}_{x} \mathrm{H}_{2-\mathrm{x}} \mathrm{Ti}_{\mathrm{y}} \mathrm{O}_{2 \mathrm{y}+1} ; 0<x<2\right.$ and $y=2,3$, or 4$)$ that assume a layered structure as shown in Figure $4[15,85]$. It is noted that the structure of the resultant sodium hydrogen titanate can be changed by the conditions of the $\mathrm{NaOH}$ treatment. Guo et al. reported the formation of $\mathrm{H}_{2} \mathrm{Ti}_{2} \mathrm{O}_{5} \bullet \mathrm{H}_{2} \mathrm{O}$ and $\mathrm{Na}_{2} \mathrm{Ti}_{2} \mathrm{O}_{5} \bullet \mathrm{H}_{2} \mathrm{O}$ on $\mathrm{Ti}$ when the metal was subjected to hydrothermal treatment using $\mathrm{NaOH}$ solution at $0.15 \mathrm{MPa}$ and $120{ }^{\circ} \mathrm{C}$ [86]. Possible compositions such as $\mathrm{Na}_{2} \mathrm{Ti}_{9} \mathrm{O}_{19}, \mathrm{Na}_{2} \mathrm{Ti}_{6} \mathrm{O}_{13}, \mathrm{Na}_{2} \mathrm{Ti}_{2} \mathrm{O}_{4}(\mathrm{OH})_{2}$, $\mathrm{Na}_{2} \mathrm{Ti}_{3} \mathrm{O}_{7} \bullet \mathrm{nH}_{2} \mathrm{O}, \mathrm{H}_{2} \mathrm{TiO}_{3} \mathrm{O}_{7}, \mathrm{H}_{2} \mathrm{Ti}_{2} \mathrm{O}_{5}, \mathrm{H}_{\mathrm{x}} \mathrm{Ti}_{2-\mathrm{x} / 4} \square_{\mathrm{x} / 4} \mathrm{O}_{4}(\square$ = vacancy) have been proposed [87-93], while the mechanism of the precipitation of the sodium hydrogen titanate in $\mathrm{NaOH}$ solution is still under investigation. When the treated metals were soaked in SBF, they formed surface apatite when the metals were soaked in an $\mathrm{NaOH}$ solution higher than $0.5 \mathrm{~mol} / \mathrm{L}$. The apatite forming capacity of the treated metal increased with the increase of the concentration, temperature and soaking period in the $\mathrm{NaOH}$ treatment. The apatite formation was attributed to the abundant $\mathrm{Ti}-\mathrm{OH}$ groups formed on the treated metals as a result of the exchange of the $\mathrm{Na}^{+}$ions in the sodium hydrogen titanate for the $\mathrm{H}_{3} \mathrm{O}^{+}$ions in SBF. This ion exchange proceeded rapidly, owing to the layered structure of sodium hydrogen titanate (Figure 4). 
(a)

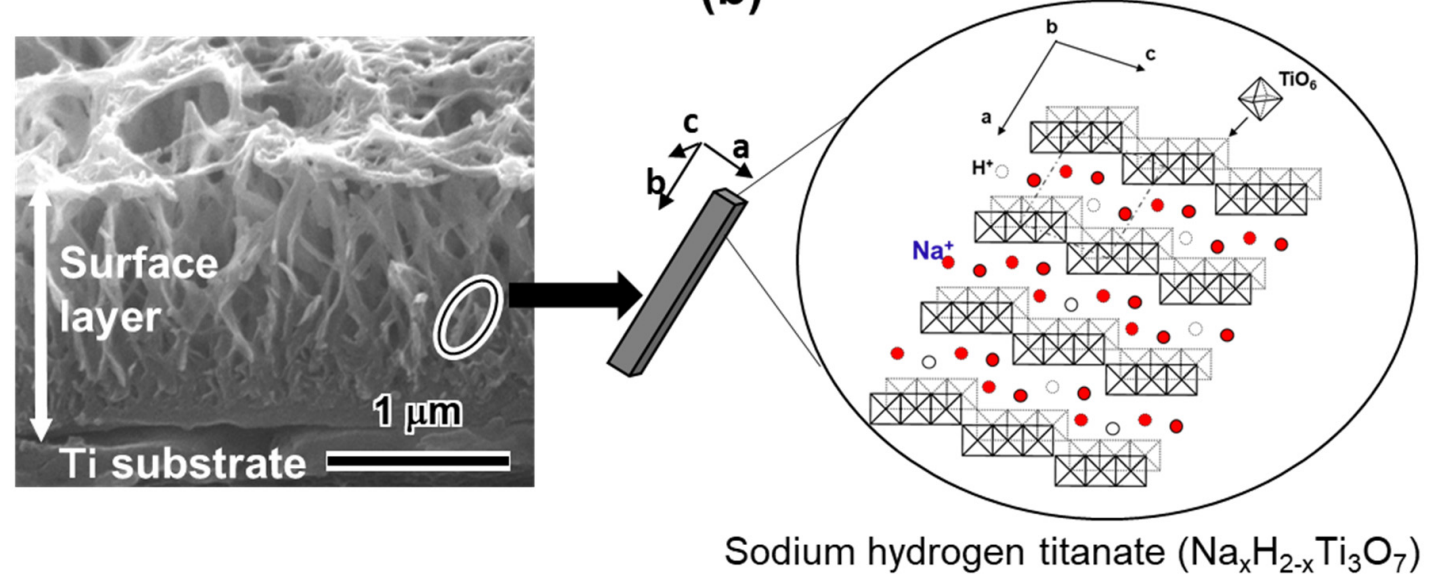

Figure 4. (a) Cross section SEM image of Ti subjected to $\mathrm{NaOH}$ treatment and (b) illustration of sodium hydrogen titanate structure. (Reproduced from (a) [15], (b) [85]).

Although the simple $\mathrm{NaOH}$ treatment successfully does confer the apatite forming capability on $\mathrm{Ti}$, the surface sodium hydrogen titanate layer that forms is mechanically weak, unstable, and the apatite formation capacity tends to be lost in the storage period before implantation or during the course of implantation [94]. Nishiguchi et al. reported the results of an in vivo test in which the detaching failure of $\mathrm{NaOH}$-treated $\mathrm{Ti}$ was comparable to that of as-polished Ti, even after 16 weeks implantation in a rabbit tibia [94]. Thus, the treated Ti was subsequently heat treated at $600{ }^{\circ} \mathrm{C}$ for $1 \mathrm{~h}$ [95]. The heat treatment markedly increased the scratch resistance of the surface layer from 5 to $50 \mathrm{mN}$ by transformation of the sodium hydrogen titanate into sodium titanate $\left(\mathrm{Na}_{2} \mathrm{Ti}_{6} \mathrm{O}_{13}\right)$ and rutile without any apparent morphological change [15]. Interestingly, the sodium titanate also took on a layered structure and showed great capacity of ion exchange $[95,96]$. Thus, the treated metal again formed apatite on its surface in SBF. The apatite formation mechanism on the $\mathrm{NaOH}$-heat treated Ti was revealed by $\mathrm{X}$-ray photoelectron spectroscopy, transmission electron microscopy equipped with energy dispersive $X$-ray analysis and zeta potential measurement [97-99]: the exchange of $\mathrm{Na}^{+}$ions and $\mathrm{H}_{3} \mathrm{O}^{+}$ ions produced not only Ti-OH groups on the metal, but also induced a local alkaline environment near the surface. As a result, the Ti-OH groups became negatively charged and combined with $\mathrm{Ca}^{2+}$ ions in SBF. As the $\mathrm{Ca}^{2+}$ ions accumulated, the surface became positively charged and combined with the $\mathrm{HPO}_{4}{ }^{2-}$ ions in SBF to form an amorphous calcium phosphate. This phase was metastable and eventually transformed into the stable, crystalline bone-like apatite.

It was not only the apatite formation that increased on the treated Ti, but also the cellular activity. Isaac et al. reported increased gene expression for bone protein markers such as alkaline phosphatase, osteocalcin, bone sialoprotein, and dentin matrix acidic phosphoprotein1, and also the expression of genes encoding the osteoblastic transcription factors Runx2, Dlx5, and Osterix [100]. It is worth mentioning that this gene expression upregulation was of the same degree on the treated Ti before and after apatite formation.

Nishighchi et al. reported that when the Ti subjected to the $\mathrm{NaOH}$ and heat treatment was implanted into a rabbit tibia, it formed an apatite layer on its surface and tightly bonded to bone within 8 weeks [94]. They also reported an intramedullary rabbit femur model in which Ti rod implants subjected to $\mathrm{NaOH}$ and heat treatment displayed greater bone formation surrounding the implants and a significantly higher pull-out failure load than polished implants starting at 3 weeks [101]. The $\mathrm{NaOH}$ and heat treatment applied to the porous Ti layer of an artificial hip joint has been in clinical use in Japan since 2007.

So et al. reviewed the long-term survivorship of the $\mathrm{NaOH}$ - and heat-treated total hip arthroplasty (THA) in 70 primary THAs, of whom 67 were available for follow-up in periods of 8-12 years [17]. Direct bone bonding, no radiographic signs of loosening, and a high survival rate of $98 \%$ at 10 years 
were reported. On the other hand, two joints had to be retrieved because of deep infection and periprosthetic femoral fracture, respectively [17]. In addition to bone bonding, the anti-bacterial and increasing bone density capacities are desirable, as these may prevent bone infection and fracture [102].

Such a multifunctional Ti may be realized by incorporating certain functional metal ions into the Ti surface by utilizing the layered structure of sodium hydrogen titanate. It is known that lithium $\left(\mathrm{Li}^{+}\right)$, calcium $\left(\mathrm{Ca}^{2+}\right)$, magnesium $\left(\mathrm{Mg}^{2+}\right)$, strontium $\left(\mathrm{Sr}^{2+}\right)$, zinc $\left(\mathrm{Zn}^{2+}\right)$, and gallium $\left(\mathrm{Ga}^{3+}\right)$ promote new bone formation, while silver $\left(\mathrm{Ag}^{+}\right)$, copper $\left(\mathrm{Cu}^{2+}\right), \mathrm{Zn}^{2+}$ and $\mathrm{Ga}^{3+}$ exhibit antibacterial activity. Yamaguchi et al. and Kizuki et al. demonstrated that these ions can be incorporated into the Ti surface despite their valences when $\mathrm{Ti}$ is soaked in a solution containing these ions following the $\mathrm{NaOH}$ treatment owing to large ion exchange capacity of sodium hydrogen titanate [103-107]. The treated metal was subjected to heat treatment because the solution-treated metal again exhibited poor scratch resistance. The introduction of $\mathrm{Ca}^{2+}$ ions effectively confers apatite formation on certain kinds of $\mathrm{Ti}-\mathrm{Zr}-\mathrm{Nb}-\mathrm{Ta}$ system alloys that are free cytotoxic elements. It is reported that the simple $\mathrm{NaOH}$-heat treatment proved ineffective for these alloys [108]. When $\mathrm{Ca}^{2+}$ ions were incorporated into the Ti-36Nb-2Ta-3Zr-0.3O alloy surface by soaking in $100 \mathrm{~mol} / \mathrm{L} \mathrm{CaCl}$ solution after $1 \mathrm{~mol} / \mathrm{L}$ $\mathrm{NaOH}$ treatment, followed by the heat treatment at $700{ }^{\circ} \mathrm{C}$, calcium titanate was formed on the alloy. The treated alloy did not form apatite in SBF since the thus formed calcium titanate was too stable to release enough $\mathrm{Ca}^{2+}$ ions to induce apatite formation. A high capacity for apatite formation was conferred on the alloy by an additional hot water treatment at $80{ }^{\circ} \mathrm{C}$ for $24 \mathrm{~h}$, which partially replaced the $\mathrm{Ca}^{2+}$ ions in the calcium titanate with $\mathrm{H}_{3} \mathrm{O}^{+}$so as to form Ca-deficient calcium titanate [108]. When the treated alloy was implanted into a rabbit tibia, strong or poor bone bonding was observed on the alloy with or without the final hot water treatment, respectively [109]. Since the hot water treatment did not apparently change the crystal structure or surface topology, the strong bone bonding that occurred after the water treatment was attributed to apatite formation. $\mathrm{Sr}^{2+}$ and $\mathrm{Mg}^{2+}$ ions can be introduced into the calcium titanate without decreasing apatite formation when these ions are mixed in the second and final solution. The Ti with Sr- or Mg-containing Ca-deficient calcium titanate exhibited higher bone bonding capacity than the metal with Ca-deficient calcium titanate, especially at the early stages of implantation [110]. This increased bone bonding capacity was attributed to the increased cellar activity due to $\mathrm{Sr}^{2+}$ and $\mathrm{Mg}^{2+}$ ions that were released from the metal surface [103,105]. It was further demonstrated that $\mathrm{Ag}^{+}$ions were controllably introduced into the Sr-containing calcium deficient calcium titanate by adding $\mathrm{Ag}^{+}$ions in the final solution treatment [111]. The treated $\mathrm{Ti}$ with $0.2 \%$ Ag exhibited potent antibacterial activity (more than $99.9 \%$ reduction) against E. coli as well as apatite formation without any cytotoxicity. The bone bonding of the treated Ti was again confirmed by animal experiment.

These reports indicate that certain surface modifications developed by means of SBF successfully conferred bone bonding capacity on Ti, which in itself is a non-bioactive material. Furthermore, the surface treatments can be designed to provide additional key functions such as the promotion of new bone formation and antibacterial activity insofar as the apatite formation in SBF is maintained. This scheme for the development of multifunctional implants utilizing SBF should prove to be a promising way to produce desired implants in a timely manner.

\section{The Role of Testing Mode: Static vs. Dynamic Conditions}

If samples are available in a bulk form (i.e., tiles or discs), static testing in SBF is typically preferred [22]. If samples are tested in the form of fine powder or particulate, dynamic conditions have been proposed in order to better mimic the physiological conditions in the body, i.e., fluid recirculation [51]. In this regard, Macon et al. [56] proposed the testing of bioactive glass particles in SBF (fixed mass-to volume ratio of $1.5 \mathrm{mf} / \mathrm{mL}$ ) under "standard" continuous agitation at $120 \mathrm{rpm}$ in an orbital shaker during immersion at $37^{\circ} \mathrm{C}$.

Zhang et al. [112] investigated the differences in terms of apatite-forming ability of $45 S 5$ glass particles (size within 500-800 $\mu \mathrm{m}$ ) during immersion in SBF for $48 \mathrm{~h}$ under both static (0.95 glass 
in $40 \mathrm{~mL}$ of SBF) and dynamic conditions, with SBF circulation (0.95 g glass, flow rate $33 \mathrm{~mL} / \mathrm{min}$ ). Apatite was shown to form on the surface of glass particles in both testing modes, but exhibited different morphologies. Under static conditions, reactions layers were generally thicker, uneven, and included a distinct calcium-phosphate layer on the top of the silica gel layer. This multilayer appearance of the surface reaction layers is not always visible so clearly; it was well detected also on the pore walls of glass-ceramic scaffolds based on a $\mathrm{SiO}_{2}-\mathrm{P}_{2} \mathrm{O}_{5}-\mathrm{CaO}-\mathrm{MgO}-\mathrm{Na}_{2} \mathrm{O}-\mathrm{K}_{2} \mathrm{O}-\mathrm{Ag} 2 \mathrm{O}$ glass system, as displayed in Figure 5 [113]. On the contrary, reactions layers formed under dynamic conditions were thinner and more uniform; furthermore, calcium phosphate inclusions were only observed in a single surface layer being mixed with silica gel [112].

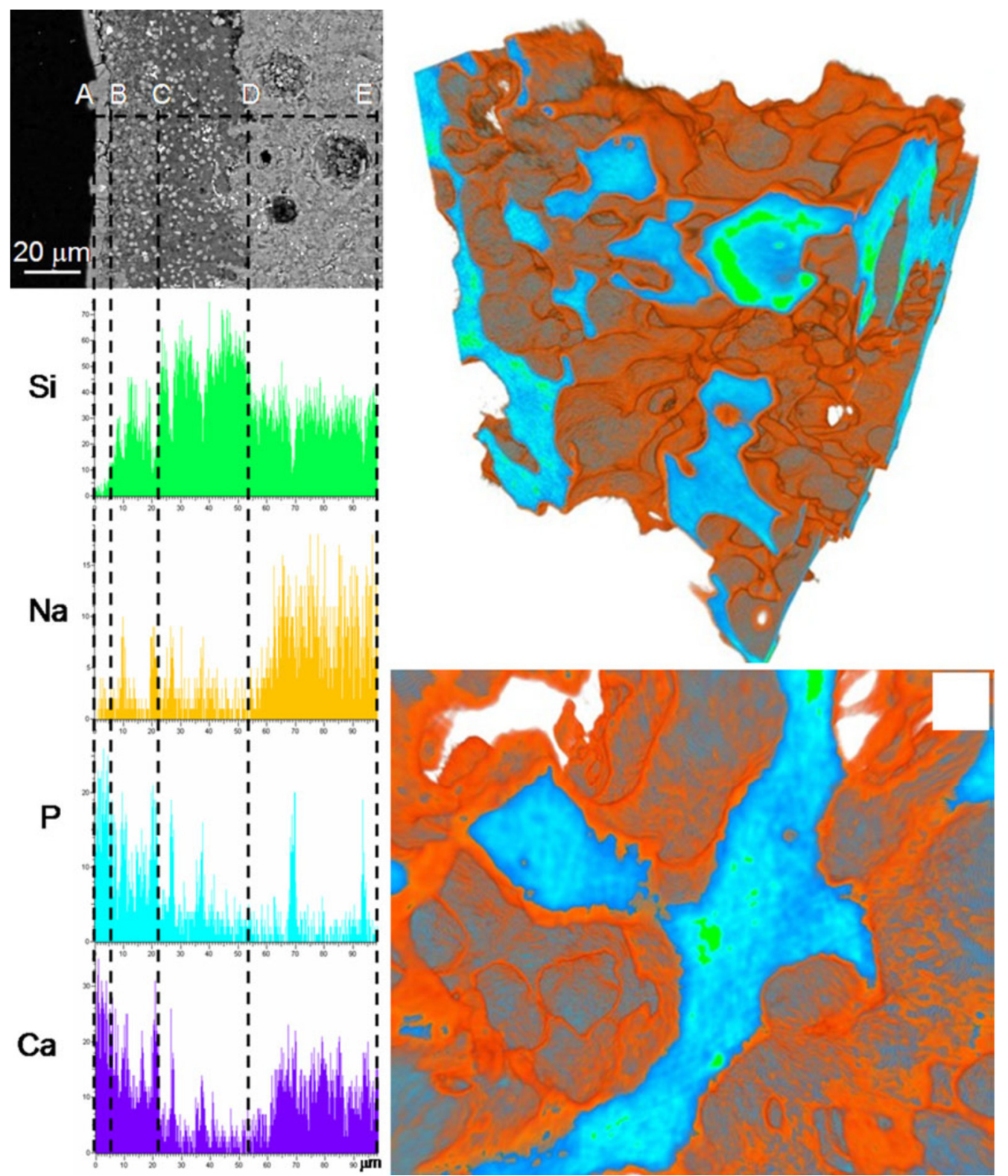

Figure 5. Results of in vitro bioactivity test on a silicate glass-ceramic scaffold: SEM-EDS analyses on a cross-section (left) and micro-tomographic three-dimensional reconstructions (right) after 14 days of immersion in SBF. Reproduced from [113] Miola, M.; Verné, E.; Vitale-Brovarone, C.; Baino, F. Antibacterial bioglass-derived scaffolds: innovative synthesis approach and characterization. Int. J. Appl. Glass Sci. 2016, 7, 238-247. Copyright 2016 John Wiley and Sons. 
A recent study reported the testing of gellan gum/sol-gel glass composite scaffolds in a perfusion bioreactor under SBF circulation [114]. The best results in terms of apatite formation on the walls of interior pores were obtained under direct SBF perfusion, while apatite only partially formed on the scaffolds immersed under static mode, with more crystals on the outer surface. This study suggests that bioactive glass conversion to apatite could be governed by the mass transfer rate and justifies future investigations for the development of effective in-vivo-like testing modes using bioreactors.

\section{Beyond Bone-Related Bioactivity}

Biomaterials community currently recognizes the use of SBF in immersion studies as a standard approach to evaluate the bioactivity of materials [22]. Indeed, the results of such in vitro assay, in terms of apatite-forming capability, are reliable only if the testing parameters are properly selected depending on the nature of the biomaterial tested: for example, the volume of SBF should be fixed according to the shape and geometry of materials, e.g., large pieces, particles, porous materials, etc. [34,58] Induction period of apatite formation in SBF enough for in vivo bone bonding should be discussed appropriately. On these points, further refinements of existing methods would need to be implemented in the future.

In the light of recent advances in biomaterials science and bioengineering, a very basic issue deserves to be considered, i.e., the need for rethinking the meaning of the term "bioactivity". In the broadest sense, a material is defined "bioactive" with reference to its ability of performing a specific function required to generate the most appropriate beneficial cellular or tissue response in a specific situation [115]. Of course, bioactivity implies biocompatibility, i.e., the material should perform its bio-function without eliciting any undesirable local or systemic effect in the host/biological environment [115]. Initially, bioactive materials were those materials that could bond to bone forming a tight and chemically-stable interface; this definition is still valid today, but a lot of experimental studies have clearly demonstrated that some materials-and, in some cases, exactly the same material, such as $45 \mathrm{~S} 5$ glass — can be suitable to regenerate both bone and a range of soft tissues, thereby showing promise for use in nerve, cardiac and skin tissue engineering [116-118]. Therefore, the particular cell or tissue response deriving from the "bioactive process" should be referred to a broad range of applications that are not restricted only to bone-bonding ability. As the word "bioactive" impressively expanded its meaning, it should be always contextualized depending on the specific application. Hence, two strictly-interlocked questions emerge. The first: "Is the testing in SBF the most suitable in vitro method to investigate the bioactivity of materials?" The answer is indeed "Yes", if the material goal is to promote bone healing (in this case, bioactivity = bone bonding and regeneration). On the contrary, if the intended application is in contact with soft tissues, the test in SBF could be misleading or meaningless - in fact, the apatite-forming capability could even be an undesired effect leading to soft tissue calcification. For example, it is estimated that the healing process of skin wounds lasts up to 14 days after the injury [119]. As a result, the dissolution rate of bioactive materials (e.g., glasses) applied for skin regeneration should be designed to somehow match this time period (ideally, the material should dissolve faster than soft tissue calcification occurs). The second question is: "What is the most suitable bioactivity test?" At present, the answer is not obvious, and, probably, will require the definition of "ad-hoc" testing methodologies depending on the specific application considered. This will be food for thought for further studies and discussions in the near future.

Author Contributions: Both authors equally contributed to conceptualization, literature search, methodology, writing-original draft preparation, writing-review and editing. All authors have read and agreed to the published version of the manuscript.

Funding: This research received no external funding.

Conflicts of Interest: The authors declare no conflict of interest. 


\section{References}

1. Ratner, B.A. A history of biomaterials. In Biomaterials Science, 2nd ed.; Ratner, B.A., Hoffman, A.S., Schoen, F.J., Lemons, J.E., Eds.; Elsevier Academic Press: London, UK, 2004; pp. 10-19.

2. Hench, L.L.; Splinter, R.J.; Allen, W.C.; Greenlee, T.K. Bonding mechanisms at the interface of ceramic prosthetic materials. J. Biomed. Mater. Res. 1971, 5, 117-141. [CrossRef]

3. Takadama, H.; Kokubo, T. In vitro evaluation of bone bioactivity. In Bioceramics and their Clinical Applications; Kokubo, T., Ed.; WoodHead Pub.: Cambridge, UK, 2008; pp. 165-198.

4. Neo, M.; Kotani, S.; Nakamura, T.; Yamamuro, T.; Ohtsuki, C.; Kokubo, T.; Bando, Y. A comparative study of ultrastructures of the interfaces between four kinds of surface-active ceramic and bone. J. Biomed. Mater. Res. 1992, 26, 1419-1432. [CrossRef] [PubMed]

5. Ogino, M.; Ohuchi, F.; Hench, L.L. Compositional dependence of the formation of calcium phosphate films on bioglass. J. Biomed. Mater. Res. 1980, 14, 55-64. [CrossRef] [PubMed]

6. Ohtsuki, C.; Kushitani, H.; Kokubo, T.; Kotani, S.; Yamamuro, T. Apatite formation on the surface of ceravital-type glass-ceramic in the body. J. Biomed. Mater. Res. 1991, 25, 1363-1370. [CrossRef] [PubMed]

7. Kokubo, T. Bioactive glass ceramics: Properties and applications. Biomaterials 1991, 12, 155-163. [CrossRef]

8. Ohtsuki, C.; Kokubo, T.; Yamamuro, T. Mechanism of apatite formation on $\mathrm{CaO}-\mathrm{SiO}_{2}-\mathrm{P}_{2} \mathrm{O}_{5}$ glasses in a simulated body fluid. J. Non-Cryst. Solids 1992, 143, 84-92. [CrossRef]

9. Li, P.; Ohtsuki, C.; Kokubo, T.; Nakanishi, K.; Soga, N.; Nakamura, T.; Yamamuro, T. Apatite formation induced by Silica Gel in a simulated body fluid. J. Am. Ceram. Soc. 1992, 75, 2094-2097. [CrossRef]

10. Li, P.; Ohtsuki, C.; Kokubo, T.; Nakanishi, K.; Soga, N.; De Groot, K. The role of hydrated silica, titania, and alumina in inducing apatite on implants. J. Biomed. Mater. Res. 1994, 28, 7-15. [CrossRef]

11. Uchida, M.; Kim, H.M.; Kokubo, T.; Nakamura, T. Bonelike apatite formation induced on zirconia gel in simulated body fluid. J. Am. Ceram. Soc. 2001, 84, 2041-2044. [CrossRef]

12. Miyazaki, T.; Kim, H.-M.; Kokubo, T.; Ohtsuki, C.; Nakamura, T. Apatite-forming ability of niobium oxide gels in a simulated body fluid. J. Ceram. Soc. Jpn. 2001, 109, 929-933. [CrossRef]

13. Miyazaki, T.; Kim, H.-M.; Kokubo, T.; Kato, H.; Nakamura, T. Induction and acceleration of bonelike apatite formation on tantalum oxide gel in simulated body fluid. J. Sol-Gel Sci. Technol. 2001, 21, 83-88. [CrossRef]

14. Kim, H.M.; Miyaji, F.; Kokubo, T.; Nakamura, T. Preparation of bioactive Ti and its alloys via simple chemical surface treatment. J. Biomed. Mater. Res. 1996, 32, 409-417. [CrossRef]

15. Yamaguchi, S.; Takadama, H.; Matsushita, T.; Nakamura, T.; Kokubo, T. Cross-sectional analysis of the surface ceramic layer developed on Ti metal by NaOH-heat treatment and soaking in SBF. J. Ceram. Soc. Jpn. 2009, 117, 1126-1130. [CrossRef]

16. Yan, W.Q.; Nakamura, T.; Kobayashi, M.; Kim, H.M.; Miyaji, F.; Kokubo, T. Bonding of chemically treated titanium implants to bone. J. Biomed. Mater. Res. 1997, 37, 267-275. [CrossRef]

17. So, K.; Kaneuji, A.; Matsumoto, T.; Matsuda, S.; Akiyama, H. Is the bone-bonding ability of a cementless total hip prosthesis enhanced by alkaline and heat treatments? Clin. Orthop. Relat. Res. 2013, 471, 3847-3855. [CrossRef]

18. Oyane, A.; Onuma, K.; Ito, A.; Kim, H.-M.; Kokubo, T.; Nakamura, T. Formation and growth of clusters in conventional and new kinds of simulated body fluids. J. Biomed. Mater. Res. 2003, 64, 339-348. [CrossRef] [PubMed]

19. Oyane, A.; Kim, H.-M.; Furuya, T.; Kokubo, T.; Miyazaki, T.; Nakamura, T. Preparation and assessment of revised simulated body fluids. J. Biomed. Mater. Res. 2003, 65, 188-195. [CrossRef]

20. Takadama, H.; Hashimoto, M.; Mizuno, M.; Kokubo, T. Round-robin test of SBDF for in vitro measurement of apatite-forming ability of synthetic materials. Phos. Res. Bull. 2004, 17, 119-125. [CrossRef]

21. ISO/FDIS 23317 Implants for surgery-in vitro evaluation for apatite-forming ability of implant materials. Int. Stand. 2007.

22. Kokubo, T.; Takadama, H. How useful is SBF in predicting in vivo bone bioactivity? Biomaterials 2006, 27, 2907-2915. [CrossRef] [PubMed]

23. Bohner, M.; Lemaitre, J. Can bioactivity be tested in vitro with SBF solution? Biomaterials 2009, 30, $2175-2179$. [CrossRef] [PubMed]

24. Pan, H.; Zhao, X.; Darvell, B.W.; Lu, W.W. Apatite-formation ability-Predictor of "bioactivity"? Acta Biomater. 2010, 6, 4181-4188. [CrossRef] 
25. Zadpoor, A.A. Relationship between in vitro apatite-forming ability measured using simulated body fluid and in vivo bioactivity of materials. Mater. Sci. Eng. C 2014, 35, 134-143. [CrossRef]

26. Nommeots-Nomm, A.; Hupa, L.; Rohanová, D.; Brauer, D.S. A review of acellular immersion tests on bioactive glasses-influence of medium on ion release and apatite formation. Int. J. Appl. Glas. Sci. 2020, 11, 537-551. [CrossRef]

27. Dorozhkin, S.V.; Dorozhkina, E.I.; Epple, M. Precipitation of carbonateapatite from a revised simulated body fluid in the presence of glucose. J. Appl. Biomater. Biomech. 2003, 1, 200-208.

28. Dorozhkin, S.V.; Dorozhkina, E.I. The influence of bovine serum albumin on the crystallization of calcium phosphates from a revised simulated body fluid. Colloids Surfaces A Physicochem. Eng. Asp. 2003, 215, 191-199. [CrossRef]

29. Dorozhkin, S.V.; Dorozhkina, E.I. Crystallization from a milk-based revised simulated body fluid. Biomed. Mater. 2007, 2, 87-92. [CrossRef]

30. Magyari, K.; Baia, L.; Vulpoi, A.L.; Simon, S.; Popescu, O.; Simon, V. Bioactivity evolution of the surface functionalized bioactive glasses. J. Biomed. Mater. Res. Part B Appl. Biomater. 2014, 103, 261-272. [CrossRef]

31. Zhao, W.; Lemaître, J.; Bowen, P. A comparative study of simulated body fluids in the presence of proteins. Acta Biomater. 2017, 53, 506-514. [CrossRef]

32. Rohanová, D.; Boccaccini, A.R.; Horkavcová, D.; Bozděchová, P.; Bezdička, P.; Častorálová, M. Is non-buffered DMEM solution a suitable medium for in vitro bioactivity tests? J. Mater. Chem. B 2014, 2, 5068-5076. [CrossRef]

33. Lusvardi, G.; Malavasi, G.; Menabue, L.; Aina, V.; Morterra, C. Fluoride-containing bioactive glasses: Surface reactivity in simulated body fluids solutions. Acta Biomater. 2009, 5, 3548-3562. [CrossRef]

34. Mozafari, M.; Banijamali, S.; Baino, F.; Kargozar, S.; Hill, R.G. Calcium carbonate: Adored and ignored in bioactivity assessment. Acta Biomater. 2019, 91, 35-47. [CrossRef] [PubMed]

35. Pantano, C.G.; Clark, A.E.; Hench, L.L. Multilayer corrosion films on bioglass surfaces. J. Am. Ceram. Soc. 1974, 57, 412-413. [CrossRef]

36. Wilson, J.; Pigott, G.H.; Schoen, F.J.; Hench, L.L. Toxicology and biocompatibility of bioglasses. J. Biomed. Mater. Res. 1981, 15, 805-817. [CrossRef] [PubMed]

37. Hench, L.L. The story of Bioglass@. J. Mater. Sci. Mater. Med. 2006, 17, 967-978. [CrossRef]

38. Henderson, G.S.; Calas, G.; Stebbins, J.F. The Structure of silicate glasses and melts. Elements 2006, 2, $269-273$. [CrossRef]

39. Jabraoui, H.; Vaills, Y.; Hasnaoui, A.; Badawi, M.; Ouaskit, S. Effect of sodium oxide modifier on structural and elastic properties of silicate glass. J. Phys. Chem. B 2016, 120, 13193-13205. [CrossRef]

40. Hill, R. An alternative view of the degradation of Bioglass. J. Mater. Sci. Lett. 1996, 15, 1122-1125. [CrossRef]

41. Fitzgerald, V.; Pickup, D.M.; Greenspan, D.; Sarkar, G.; Fitzgerald, J.J.; Wetherall, K.M.; Moss, R.M.; Jones, J.R.; Newport, R. A neutron and X-Ray diffraction study of Bioglass@with reverse Monte Carlo modelling. Adv. Funct. Mater. 2007, 17, 3746-3753. [CrossRef]

42. Rahaman, M.N.; Day, D.E.; Bal, B.S.; Fu, Q.; Jung, S.B.; Bonewald, L.F.; Tomsia, A.P. Bioactive glass in tissue engineering. Acta Biomater. 2011, 7, 2355-2373. [CrossRef]

43. Kokubo, T.; Ito, S.; Sakka, S.; Yamamuro, T. Formation of a high-strength bioactive glass-ceramic in the system $\mathrm{MgO}-\mathrm{CaO}-\mathrm{SiO}_{2}-\mathrm{P}_{2} \mathrm{O}_{5}$. J. Mater. Sci. 1986, 21, 536-540. [CrossRef]

44. Peitl, O.; LaTorre, G.P.; Hench, L.L. Effect of crystallization on apatite layer formation of bioactive glass $45 \mathrm{~S} 5$. J. Biomed. Mater. Res. 1996, 30, 509-514.

45. Balasubramanian, P.; Büttner, T.; Pacheco, V.M.; Boccaccini, A.R. Boron-containing bioactive glasses in bone and soft tissue engineering. J. Eur. Ceram. Soc. 2018, 38, 855-869. [CrossRef]

46. Knowles, J.C. Phosphate based glasses for biomedical applications. J. Mater. Chem. 2003, 13, $2395-2401$. [CrossRef]

47. Leonardi, E.; Ciapetti, G.; Baldini, N.; Novajra, G.; Verne', E.; Baino, F.; Vitale-Brovarone, C. Response of human bone marrow stromal cells to a resorbable $\mathrm{P}_{2} \mathrm{O}_{5}-\mathrm{SiO}_{2}-\mathrm{CaO}-\mathrm{MgO}-\mathrm{Na}_{2} \mathrm{O}-\mathrm{K}_{2} \mathrm{O}$ phosphate glass ceramic for tissue engineering applications. Acta Biomater. 2010, 6, 598-606. [CrossRef]

48. Neel, E.A.A.; Pickup, D.M.; Valappil, S.P.; Newport, R.J.; Knowles, J.C. Bioactive functional materials: A perspective on phosphate-based glasses. J. Mater. Chem. 2009, 19, 690-701. [CrossRef]

49. Izquierdo-Barba, I.; Vallet-Regí, M. Mesoporous bioactive glasses: Relevance of their porous structure compared to that of classical bioglasses. Biomed. Glas. 2015, 1, 140-150. [CrossRef] 
50. Cao, W.; Hench, L.L. Bioactive materials. Ceram. Int. 1996, 22, 493-507. [CrossRef]

51. Avnir, D.; Coradin, T.; Lev, O.; Livage, J. Recent bio-applications of sol-gel materials. J. Mater. Chem. 2006, 16, 1013-1030. [CrossRef]

52. Wu, C.; Chang, J. Mesoporous bioactive glasses: Structure characteristics, drug/growth factor delivery and bone regeneration application. Interface Focus 2012, 2, 292-306. [CrossRef]

53. Baino, F.; Fiorilli, S.; Mortera, R.; Onida, B.; Saino, E.; Visai, L.; Verné, E.; Vitale-Brovarone, C. Mesoporous bioactive glass as a multifunctional system for bone regeneration and controlled drug release. J. Appl. Biomater. Funct. Mater. 2012, 10, 12-21.

54. Horcajada, P.; Ramila, A.; Boulahya, K.; Vitale-Brovarone, C.; Vallet-Regí, M. Bioactivity in ordered mesoporous materials. Solid State Sci. 2004, 6, 1295-1300. [CrossRef]

55. Izquierdo-Barba, I.; Ruiz-González, L.; Doadrio, J.C.; González-Calbet, J.M.; Vallet-Regí, M. Tissue regeneration: A new property of mesoporous materials. Solid State Sci. 2005, 7, 983-989. [CrossRef]

56. Fiume, E.; Migneco, C.; Verné, E.; Baino, F. Comparison between bioactive sol-gel and melt-derived glasses/glass-ceramics based on the multicomponent $\mathrm{SiO}_{2}-\mathrm{P}_{2} \mathrm{O}_{5}-\mathrm{CaO}-\mathrm{MgO}-\mathrm{Na}_{2} \mathrm{O}-\mathrm{K}_{2} \mathrm{O}$ System. Materials 2020, 13, 540. [CrossRef]

57. Sepulveda, P.; Jones, J.R.; Hench, L.L. In vitro dissolution of melt-derived $45 \mathrm{~S} 5$ and sol-gel derived 58S bioactive glasses. J. Biomed. Mater. Res. 2002, 61, 301-311. [CrossRef]

58. Maçon, A.L.B.; Kim, T.B.; Valliant, E.M.; Goetschius, K.; Brow, R.K.; Day, D.E.; Hoppe, A.; Boccaccini, A.R.; Kim, I.Y.; Ohtsuki, C.; et al. A unified in vitro evaluation for apatite-forming ability of bioactive glasses and their variants. J. Mater. Sci. Mater. Med. 2015, 26, 115. [CrossRef]

59. Baino, F.; Fiume, E.; Miola, M.; Verné, E. Bioactive sol-gel glasses: Processing, properties, and applications. Int. J. Appl. Ceram. Technol. 2018, 15, 841-860. [CrossRef]

60. Mačković, M.; Hoppe, A.; Detsch, R.; Möhn, D.; Stark, W.J.; Spiecker, E.; Boccaccini, A.R. Bioactive glass (type 45S5) nanoparticles: In vitro reactivity on nanoscale and biocompatibility. J. Nanoparticle Res. 2012, 14, 966. [CrossRef]

61. Brückner, R.; Tylkowski, M.; Hupa, L.; Brauer, D.S. Controlling the ion release from mixed alkali bioactive glasses by varying modifier ionic radii and molar volume. J. Mater. Chem. B 2016, 4, 3121-3134. [CrossRef] [PubMed]

62. O'Donnell, M.; Hill, R. Influence of strontium and the importance of glass chemistry and structure when designing bioactive glasses for bone regeneration. Acta Biomater. 2010, 6, 2382-2385. [CrossRef]

63. Wennerberg, A.; Albrektsson, T. Effects of titanium surface topography on bone integration: A systematic review. Clin. Oral Implant. Res. 2009, 20, 172-184. [CrossRef]

64. Damiati, L.; Eales, M.G.; Nobbs, A.H.; Su, B.; Tsimbouri, P.M.; Salmeron-Sanchez, M.; Dalby, M.J. Impact of surface topography and coating on osteogenesis and bacterial attachment on titanium implants. J. Tissue Eng. 2018, 9, 1-16. [CrossRef] [PubMed]

65. Aparicio, C.; Gil, F.J.; Fonseca, C.; Barbosa, M.; Planell, J.A. Corrosion behaviour of commercially pure titaniumshot blasted with different materials and sizes of shot particlesfor dental implant applications. Biomaterials 2003, 24, 263-273. [CrossRef]

66. Yang, G.-L.; He, F.-M.; Yang, X.-F.; Wang, X.-X.; Zhao, S.-F. Bone responses to titanium implants surface-roughened by sandblasted and double etched treatments in a rabbit model. Oral Surg. Oral Med. Oral Pathol. Oral Radiol. Endodontol. 2008, 106, 516-524. [CrossRef] [PubMed]

67. Coelho, P.G.; Granjeiro, J.M.; Romanos, G.E.; Suzuki, M.; Silva, N.R.F.; Cardaropoli, G.; Thompson, V.P.; Lemons, J.E. Basic research methods and current trends of dental implant surfaces. J. Biomed. Mater. Res. Part B Appl. Biomater. 2009, 88, 579-596. [CrossRef]

68. Bagno, A.; Di Bello, C. Surface treatments and roughness properties of Ti-based biomaterials. J. Mater. Sci. Mater. Electron. 2004, 15, 935-949. [CrossRef]

69. Hacking, S.A.; Tanzer, M.; Harvey, E.J.; Krygier, J.J.; Bobyn, J.D. Relative contributions of chemistry and topography to the osseointegration of hydroxyapatite coatings. Clin. Orthop. Relat. Res. 2002, 405, 24-38. [CrossRef]

70. Sawaguchi, H.; Xu, J.; Kawai, T.; Mineta, T.; Nonomura, Y. Formation process of apatite layer on titanium-coated silicon wafer surfaces. J. Ceram. Soc. Jpn. 2016, 124, 753-756. [CrossRef]

71. Chen, X.; Nouri, A.; Li, Y.; Lin, J.; Hodgson, P.D.; Wen, C.E. Effect of surface roughness of Ti, Zr, and TiZr on apatite precipitation from simulated body fluid. Biotechnol. Bioeng. 2008, 101, 378-387. [CrossRef] 
72. Sugino, A.; Ohtsuki, C.; Tsuru, K.; Hayakawa, S.; Nakano, T.; Okazaki, Y.; Osaka, A. Effect of spatial design and thermal oxidation on apatite formation on Ti-15Zr-4Ta-4Nb alloy. Acta Biomater. 2009, 5, 298-304. [CrossRef]

73. Klawitter, J.J.; Weinstein, A.M. The status of porous materials to obtain direct skeletal attachment by tissue ingrowth. Acta Orthop. Belg. 1974, 40, 755-765.

74. Spector, M.; Michno, M.J.; Smarook, W.H.; Kwiatkowski, G.T. A high-modulus polymer for porous orthopedic implants: Biomechanical compatibility of porous implants. J. Biomed. Mater. Res. 1978, 12, 665-677. [CrossRef] [PubMed]

75. Hahn, H.; Palich, W. Preliminary evaluation of porous metal surfaced titanium for orthopedic implants. J. Biomed. Mater. Res. 1970, 4, 571-577. [CrossRef] [PubMed]

76. Karageorgiou, V.; Kaplan, D. Porosity of 3D biomaterial scaffolds and osteogenesis. Biomaterials 2005, 26, 5474-5491. [CrossRef]

77. Van Der Stok, J.; Van Der Jagt, O.; Yavari, S.A.; De Haas, M.; Waarsing, J.; Jahr, H.; Van Lieshout, E.; Patka, P.; Verhaar, J.; Zadpoor, A.A.; et al. Selective laser melting-produced porous titanium scaffolds regenerate bone in critical size cortical bone defects. J. Orthop. Res. 2012, 31, 792-799. [CrossRef] [PubMed]

78. Wu, S.-H.; Li, Y.; Zhang, Y.-Q.; Li, X.-K.; Yuan, C.-F.; Hao, Y.-L.; Zhang, Z.-Y.; Guo, Z. Porous titanium-6 aluminum-4 vanadium cage has better osseointegration and less micromotion than a poly-ether-ether-ketone cage in sheep vertebral fusion. Artif. Organs 2013, 37, E191-E201. [CrossRef] [PubMed]

79. Yang, J.; Cai, H.; Lv, J.; Zhang, K.; Leng, H.; Sun, C.; Wang, Z.; Liu, Z. In Vivo study of a self-stabilizing artificial vertebral body fabricated by electron beam melting. Spine 2014, 39, E486-E492. [CrossRef]

80. Taniguchi, N.; Fujibayashi, S.; Takemoto, M.; Sasaki, K.; Otsuki, B.; Nakamura, T.; Matsushita, T.; Kokubo, T.; Matsuda, S. Effect of pore size on bone ingrowth into porous titanium implants fabricated by additive manufacturing: An in vivo experiment. Mater. Sci. Eng. C 2016, 59, 690-701. [CrossRef]

81. Takemoto, M.; Fujibayashi, S.; Neo, M.; Suzuki, J.; Kokubo, T.; Nakamura, T. Mechanical properties and osteoconductivity of porous bioactive titanium. Biomaterials 2005, 26, 6014-6023. [CrossRef]

82. Takemoto, M.; Fujibayashi, S.; Neo, M.; Suzuki, J.; Matsushita, T.; Kokubo, T.; Nakamura, T. Osteoinductive porous titanium implants: Effect of sodium removal by dilute $\mathrm{HCl}$ treatment. Biomaterials 2006, 27, 2682-2691. [CrossRef]

83. Spriano, S.; Yamaguchi, S.; Baino, F.; Ferraris, S. A critical review of multifunctional titanium surfaces: New frontiers for improving osseointegration and host response, avoiding bacteria contamination. Acta Biomater. 2018, 79, 1-22. [CrossRef]

84. Kim, H.-M.; Miyaji, F.; Kokubo, T.; Nakamura, T. Apatite-forming ability of alkali-treated Ti metal in body environment. J. Ceram. Soc. Jpn. 1997, 105, 111-116. [CrossRef]

85. Kokubo, T.; Yamaguchi, S. Novel bioactive titanate layers formed on Ti metal and its alloys by chemical treatments. Materials 2009, 3, 48-63. [CrossRef]

86. Guo, Z.; Jiang, N.; Chen, C.; Zhu, S.; Zhang, L.; Li, Y. Surface bioactivation through the nanostructured layer on titanium modified by facile HPT treatment. Sci. Rep. 2017, 7, 4155. [CrossRef] [PubMed]

87. Ma, R.; Fukuda, K.; Sasaki, T.; Osada, A.M.; Bando, Y. Structural features of titanate nanotubes/nanobelts revealed by raman, $\mathrm{X}$-ray absorption fine structure and electron diffraction characterizations. J. Phys. Chem. B 2005, 109, 6210-6214. [CrossRef]

88. Chen, C.-Y.; Ozasa, K.; Katsumata, K.-I.; Maeda, M.; Okada, K.; Matsushita, N. Bioactive titanium oxide-based nanostructures prepared by one-step hydrothermal anodization. J. Phys. Chem. C 2012, 116, 8054-8062. [CrossRef]

89. Chen, X.; Mao, S.S. Titanium dioxide nanomaterials: Synthesis, properties, modifications, and applications. Chem. Rev. 2007, 107, 2891-2959. [CrossRef] [PubMed]

90. Kukovecz, A.; Hodos, M.; Horváth, E.; Radnóczi, G.; Kónya, Z.; Kiricsi, I. Oriented crystal growth model explains the formation of titania nanotubes. J. Phys. Chem. B 2005, 109, 17781-17783. [CrossRef]

91. Kasuga, T.; Hiramatsu, M.; Hoson, A.; Sekino, T.; Niihara, K. Formation of titanium oxide nanotube. Langmuir 1998, 14, 3160-3163. [CrossRef]

92. Chen, Q.; Zhou, W.; Du, G.; Peng, L.-M. Trititanate nanotubes made via a single alkali treatment. Adv. Mater. 2002, 14, 1208-1211. [CrossRef] 
93. Wang, H.; Lai, Y.; Zhang, R.; Rian, Y.; Zhang, K.; Lin, C. Tuning the surface microstructure of titanate coating on titanium implant of enchacing bioactivity of implants. Int. J. Nanomed. 2015, 10, 3887-3896. [CrossRef] [PubMed]

94. Nishiguchi, S.; Nakamura, T.; Kobayashi, M.; Kim, H.-M.; Miyaji, F.; Kokubo, T. The effect of heat treatment on bone-bonding ability of alkali-treated titanium. Biomaterials 1999, 20, 491-500. [CrossRef]

95. Kim, H.-M.; Miyaji, F.; Kokubo, T.; Nakamura, T. Effect of heat treatment on apatite-forming ability of Ti metal induced by alkali treatment. J. Mater. Sci. Mater. Electron. 1997, 8, 341-347. [CrossRef] [PubMed]

96. Luo, L.; Zhen, Y.; Lu, Y.; Zhou, K.; Huang, J.; Huang, Z.; Mathur, S.; Hong, Z. Structural evolution from layered $\mathrm{Na}_{2} \mathrm{Ti}_{3} \mathrm{O}_{7}$ to $\mathrm{Na}_{2} \mathrm{Ti}_{6} \mathrm{O}_{13}$ nanowires enabling a highly reversible anode for Mg-ion batteries. Nanoscale 2020, 12, 230-238. [CrossRef]

97. Kim, H.; Himeno, T.; Kawashita, M.; Lee, J.; Kokubo, T.; Nakamura, T. Surface potential change in bioactive titanium metal during the process of apatite formation in simulated body fluid. J. Biomed. Mater. Res. Part A 2003, 67, 1305-1309. [CrossRef] [PubMed]

98. Takadama, H.; Kim, H.M.; Kokubo, T.; Nakamura, T. An X-ray photoelectron spectroscopy study of the process of apatite formation on bioactive titanium metal. J. Biomed. Mater. Res. 2001, 55, 185-193. [CrossRef]

99. Takadama, H.; Kim, H.-M.; Kokubo, T.; Nakamura, T. TEM-EDX study of mechanism of bonelike apatite formation on bioactive titanium metal in simulated body fluid. J. Biomed. Mater. Res. 2001, 57, 441-448. [CrossRef]

100. Isaac, J.; Galtayries, A.; Kizuki, T.; Kokubo, T.; Berda, A.; Sautier, J.M. Bioengineered titanium surfaces affect the gene-expression and phenotypic response of osteoprogenitor cells derived from mouse calvarial bones. Eur. Cells Mater. 2010, 20, 178-196. [CrossRef]

101. Nishiguchi, S.; Fujibayashi, S.; Kim, H.-M.; Kokubo, T.; Nakamura, T. Biology of alkali-and heat-treated titanium implants. J. Biomed. Mater. Res. 2003, 67, 26-35. [CrossRef]

102. Orapiriyakul, W.; Young, P.S.; Damiati, L.; Tsimbouri, P.M. Antibacterial surface modification of titanium implants in orthopaedics. J. Tissue Eng. 2018, 9. [CrossRef]

103. Yamaguchi, S.; Matsushita, T.; Kokubo, T. A bioactive Ti metal with a Ca-enriched surface layer releases $\mathrm{Mg}$ ions. RSC Adv. 2013, 3, 11274-11282. [CrossRef]

104. Yamaguchi, S.; Nath, S.; Matsushita, T.; Kokubo, T. Controlled release of strontium ions from a bioactive Ti metal with a Ca-enriched surface layer. Acta Biomater. 2014, 10, 2282-2289. [CrossRef]

105. Yamaguchi, S.; Matsushita, T.; Nakamura, T.; Kokubo, T. Bioactive Ti metal with Ca-enriched surface layer able to release Zn ion. Key Eng. Mater. 2012, 529, 547-552. [CrossRef]

106. Kizuki, T.; Matsushita, T.; Kokubo, T. Antibacterial and bioactive calcium titanate layers formed on Ti metal and its alloys. J. Mater. Sci. Mater. Electron. 2014, 25, 1737-1746. [CrossRef]

107. Yamaguchi, S.; Nath, S.; Sugawara, Y.; Divakarla, K.; Das, T.; Manos, J.; Chrzanowski, W.; Matsushita, T.; Kokubo, T. Two-in-one biointerfaces-Antimicrobial and bioactive nanoporous Gallium titanate layers for titanium implants. Nanomaterials 2017, 7, 229. [CrossRef]

108. Yamaguchi, S.; Kizuki, T.; Takadama, H.; Matsushita, T.; Nakamura, T.; Kokubo, T. Formation of a bioactive calcium titanate layer on gum metal by chemical treatment. J. Mater. Sci. Mater. Med. 2012, 23, 873-883. [CrossRef]

109. Tanaka, M.; Takemoto, M.; Fujibayashi, S.; Kawai, T.; Yamaguchi, S.; Kizuki, T.; Matsushita, T.; Kokubo, T.; Nakamura, T.; Matsuda, S. Bone bonding ability of a chemically and thermally treated low elastic modulus Ti alloy: Gum metal. J. Mater. Sci. Mater. Electron. 2013, 25, 635-643. [CrossRef]

110. Okuzu, Y.; Fujibayashi, S.; Yamaguchi, S.; Yamamoto, K.; Shimizu, T.; Sono, T.; Goto, K.; Otsuki, B.; Matsushita, T.; Kokubo, T.; et al. Strontium and magnesium ions released from bioactive titanium metal promote early bone bonding in a rabbit implant model. Acta Biomater. 2017, 63, 383-392. [CrossRef]

111. Yamaguchi, S.; Le, P.T.M.; Ito, M.; Shintani, S.A.; Takadama, H. Tri-functional Calcium-deficient Calcium Titanate coating on Titanium metal by chemical and heat treatment. Coatings 2019, 9, 561. [CrossRef]

112. Zhang, D.; Hupa, M.; Aro, H.T.; Hupa, L. Influence of fluid circulation on in vitro reactivity of bioactive glass particles. Mater. Chem. Phys. 2008, 111, 497-502. [CrossRef]

113. Miola, M.; Vernè, E.; Vitale-Brovarone, C.; Baino, F. Antibacterial Bioglass-derived scaffolds: Innovative synthesis approach and characterization. Int. J. Appl. Glas. Sci. 2016, 7, 238-247. [CrossRef] 
114. Zvicer, J.; Medic, A.; Veljovic, D.; Jevtic, S.; Novak, S.; Obradovic, B. Biomimetic characterization reveals enhancement of hydroxyapatite formation by fluid flow in gellan gum and bioactive glass composite scaffolds. Polym. Test. 2019, 76, 464-472. [CrossRef]

115. Williams, D.F. On the mechanisms of biocompatibility. Biomaterials 2008, 29, 2941-2953. [CrossRef] [PubMed]

116. Baino, F.; Novajra, G.; Miguez-Pacheco, V.; Boccaccini, A.R.; Vitale-Brovarone, C. Bioactive glasses: Special applications outside the skeletal system. J. Non-Cryst. Solids 2016, 432, 15-30. [CrossRef]

117. Kargozar, S.; Hamzehlou, S.; Baino, F. Potential of bioactive glasses for cardiac and pulmonary tissue engineering. Materials 2017, 10, 1429. [CrossRef]

118. Kargozar, S.; Hamzehlou, S.; Baino, F. Can bioactive glasses be useful to accelerate the healing of epithelial tissues? Mater. Sci. Eng. C 2019, 97, 1009-1020. [CrossRef] [PubMed]

119. Gonzalez, A.C.D.O.; Costa, T.F.; Andrade, Z.D.A.; Medrado, A.R.A.P. Wound healing-A literature review. An. Bras. Dermatol. 2016, 91, 614-620. [CrossRef] [PubMed]

Publisher's Note: MDPI stays neutral with regard to jurisdictional claims in published maps and institutional affiliations.

(C) 2020 by the authors. Licensee MDPI, Basel, Switzerland. This article is an open access article distributed under the terms and conditions of the Creative Commons Attribution (CC BY) license (http://creativecommons.org/licenses/by/4.0/). 